\title{
Folk etymology and contamination in the Romance languages
}

\section{Martin Maiden}

\section{Summary}

'Folk etymology' and 'contamination' each involve associative formal influences between words which have no 'etymological' (i.e., historical), connexion. From a morphological perspective, in folk etymology a word acquires at least some elements of the structure of some other, historically unrelated, word. The result often looks like a compound, of a word composed of other, independently existing, words. These are usually (but not necessarily) 'compounds' lacking in any semantic compositionality, which do not 'make sense': e.g., French beaupré 'bowsprit', but apparently 'beautiful meadow', possibly derived from English bowsprit. Typically involved are relatively long, polysyllabic, words, characteristically belonging to erudite or exotic vocabulary, whose unfamiliarity is accommodated by speakers unfamiliar with the target word through replacement of portions of that word with more familiar words. Contamination differs from folk etymology both on the formal and on the semantic side, usually involving non-morphemic elements, and acting between words which are semantically linked: e.g., Spanish nuera 'daughter-in-law', instead of etymologically expected **nora, apparently influenced by the vowel historically underlying suegra 'mother-in-law'. While there is nothing uniquely Romance about these phenomena, Romance languages abound in them.

Keywords: folk etymology; contamination; morphology; etymology; compounding; semantics; transparency; popular usage

\section{The concepts}

The phenomena labelled 'folk etymology' (Fr. 'étymologie populaire' and similar terms in other Romance languages; henceforth FE) and 'contamination' have long occupied an undeservedly marginal place in historical linguistics, and certainly in histories of the Romance languages. These two terms will be retained here because they are sanctioned by long-established usage, but they are misleading. 'Folk etymology' has little to do with 'etymology' understood as the 'study of the historical origin of words', while 'contamination' bears inappropriately pejorative connotations, evocative even of disease. The term 'folk' (or 'popular') may have a rather condescending ring (see Béguelin 2007), implying a difference between erudite etymology, as practised by academic linguists, and the structural and semantic reanalyses spontaneously produced by ordinary people ('folk'). 'Folk etymology' can, indeed, involve strange and even comical results, displaying speakers' ignorance of the historically correct structure and origin of the words affected, and provoking the rather common academic treatment of such developments as 'aberrant', 'amusing', 'grotesque', 'reprehensible' (see Orr 1963:1). A perhaps better, but less commonly used, term for $F E$ is 'paronymic attraction' (cf. Dauzat 1946:109), or 'paronomasia', correctly suggesting structural interference between words synchronically copresent in the lexicon. A further factor in the perception of these phenomena as marginal, is their erratic, idiosyncratic, and unpredictable nature, which often sees them relegated to appendices in histories of individual languages and language-families (cf. Béguelin 2007:20). None the less, the historical analysis of the Romance languages, and perhaps especially of French, has yielded a significant portion of the examples of $F E$ and of contamination to be found in the general linguistic literature.

\section{Folk etymology}

The class of phenomena defined in the historical linguistic literature as 'folk etymology', and as 'contamination' has in common that its members involve associative influences between words 
which normally have no historical 'etymological' connexion. There is always some kind of semantic connexion in synchrony underlying 'contamination', but we shall see that this is not necessarily, or even normally, true for $F E$. Our focus here is on changes in the form of words which can be ascribed neither to sound change nor to 'analogy', at least if we understand by the latter the replication of existing patterns of correspondence between form and meaning. It needs to be recognized, however, that there are phenomena which deserve the label 'folk etymology', but involve semantic (rather than formal) changes, prompted by perceived connexions between the form of one word and that of some other word of different meaning. French péage [peaz] 'toll, turnpike, place where one pays to use a road' is a derived word formed from continuants of Latin PES, PEDIS 'foot' and of the derivational suffix -ATICUM. Historically, the word has to do with 'feet', not 'payment'. Yet an accidental phonological resemblance, and a clear semantic connexion, reportedly (cf. Orr 1963:1f.;6) lead many French speakers to discern in péage the root of the verb payer [peje] 'to pay', ultimately derived from Latin PACARE 'pacify, settle (a price, etc.)'. An example made famous by Jules Gilliéron (e.g., Gilliéron 1918), is the French word essaim 'swarm (of bees, etc.)'. Historically, many French dialects had the word es 'bee' $[\varepsilon s]$, derived from Latin APIS. Now, essaim in fact comes from Latin EXAMEN 'swarm, crowd' (standard French pronunciation $[\varepsilon s \tilde{\varepsilon}]$ ), in turn historically made up of EX- 'out' and AGMEN 'column, procession, army on the march'. The two words are etymologically unconnected, but the shared element [es] allegedly leads speakers to identify the word for 'bee' in essaim (cf. Orr

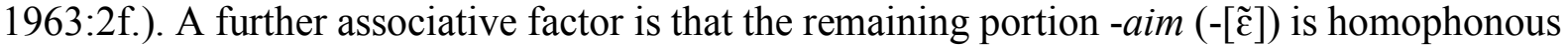
with a common derivational suffix expressing collective meaning. The word seems to comprise elements which jointly mean 'collection of bees', i.e., 'swarm'. Perceived associations of this kind can, indeed, lead to semantic change. French imbriqué 'imbricated', 'overlapping in the manner of tiles, fish scales, etc.', is an adjective ultimately derived from Latin IMBREX 'tile'. Yet it clearly evokes in French the noun brique 'brick' (a loanword from Germanic), and there are cases (see Orr 1963:9f.) where the context in which it is used reveals that the word has been taken by speakers to mean something like 'being part of some structure, in the manner of a brick'.

Semantically-based folk etymological reanalyses will not occupy us further here (although it should be noted that for some scholars, e.g., Gilliéron, they seem to have constituted the more important part of FE: cf. Lauwers 2002:84n19). In morphological FE a word acquires elements of the structure of some other word or words. The result often looks like the creation of a compound, of a word composed of other, independently existing, words (or lexical formatives). They are usually (but not necessarily) 'compounds', but ones that lack in any semantic compositionality: in short, they do not 'make sense'. Typically involved are relatively long, polysyllabic, words, characteristically belonging to erudite or exotic vocabulary, whose relative unfamiliarity is accommodated by speakers unfamiliar with the target word through replacement of portions of that word with more familiar words. It is quite often assumed (e.g., Pisani 1960:643; Kilani-Schoch 1988:91; Bolinger 1992:29; Pöck1, Rainer, and Pöll 2003:41) that $F E$ is a matter of lending 'semantic motivation' to unfamiliar words by replacing portions of them with elements that help 'make sense' of them. Indeed, this does sometimes appear to be the case, but clear Romance examples are truly difficult to find. One might cite: Calabrian rotamobbuli lit. 'mobile wheel' (< Italian automobile) and also altomobile ( + alto 'high') in Trieste (Wartburg 1925:18); Romanian (substandard) incuibație or incuibație 'incubation' (< standard Romanian incubație ( $+\hat{\imath} n$ 'in') + cuib 'nest'); French choucroute ( $<$ Alsatian surchrut (= German Sauerkraut) + chou 'cabbage' possibly combined with crôte 'crust'); popular Spanish vagamundo 'globetrotter', lit. 'wander-world' (< vagabundo 'vagabond' + mundo 'world'). For partial motivation in $F E$ see also Coates (1987:323f.). Even in such cases, apparent semantic 'motivation' is not always straightforward. An 'automobile' has 'wheels' but is not 'a wheel', nor is it inherently 'high' (although one might argue that one is higher off the road in it 
than one is on foot); 'incubation' may happen 'in nests', but it does not inherently do so, and presumably never does so in the medical or scientific context in which the term is most often used. In reality, such apparently clear cases constitute a minority. The majority of examples of morphological $F E$ in Romance languages (and generally: see Maiden 2008) do not motivate words semantically, they do not 'make sense', and indeed in many cases make 'nonsense', sometimes even comical and potentially misleading nonsense (see Baldinger 1973), by introducing elements whose meanings have nothing to do with the word affected.

To take some examples from Italo-Romance (see particularly Alessio 1937/1938; Bertolotti 1958), we could cite the following: Italian Campidoglio (a toponym in Rome) $<$ Latin CAPITOLIUM ( + campi 'fields' + d'oglio 'of oil'); battisuocera 'cornflower' < Latin BAPTISECULA $(+$ batti 'beat' + suocera 'mother-in-law'); gelsomino 'jasmine' < Persian yasmi:n $(+$ gelso 'mulberry'); bergamotto 'bergamot' < Turkish beg armudl (+ Bergamo (a toponym) + derivational suffix -otto); bompresso 'bowsprit' < French beaupré $(+b(u)$ on 'good' + presso 'near, at'); Arpinate (southern Italo-Romance) taumaturco 'silly' < Italian taumaturgo 'miracle worker' (+ turco 'Turk'); Abruzzese (southern Italo-Romance) kampo'moillo 'camomile' < Italian camomilla (+ campo 'field'); Catanzarese (southern Italo-Romance) bekkamortu 'bergamot' < It. bergamotto (+ local bekkamortu 'gravedigger'); animahju'rita 'hermaphrodite (goat)' < ('krapa) *armahju'rita < Greek HERMAPHRODITES (+ local 'arma 'soul', influenced by Italian anima 'soul', + hju'rita 'floral, flowery'); Cosentino para'gustə 'gate to choir stall in a church' < Italian balaustra (+ local 'para 'stop, ward off' and 'gustə 'taste').

Romanian (see, e.g., Hristea 1958) has standard chirpici 'sun-dried brick of mud, straw and dung' < Turkish kerpiç, but also FE variants such as cârpici (+ cârpă 'rag, duster'), cipici (+ cipic 'type of slipper'), ciupici (+ a ciupi 'pinch'), clipici (+ a clipi 'blink, wink') all followed by the common derivational suffix -ici. For standard Romanian filigran 'filigree', we have filigram < filigran (+ -gram, a common element in technical expressions, such as telegram 'telegram'), or Portocalia 'Portugal' < Portugalia 'Portugal' (+ portocală 'orange'). Standard Romanian pârău 'stream' (probably a loan from Albanian) frequently becomes pârâu, showing the influence of râu 'river'. Standard French has some $F E$ forms such as agonir 'hurl mortal insults' (< ahonir 'shame' + agonie 'death throe'); chat-huant 'tawny owl' < chouan ( + chat 'cat' + huant 'hooting'); beaupré (< English bowsprit + beau 'beautiful' + pré 'meadow'). Reported dialectal forms include the dish cresson à la noix < cresson orlenois ( + à la noix 'with nuts', but guaranteed nut-free!); mouche catholique < mouche cantharide 'Spanish fly' (+ catholique 'Catholic'); courte-pointe, contre-pointe 'counterpane' < coute-pointe $(+$ courte 'short' / contre 'against'); pomme d'amour 'love apple' (< It. pomo dei mori (lit. 'fruit of the Moors') + amour 'love'); diablette 'diabetes' < (diabète + diable 'devil').

While $F E$ often has the effect of conferring the structure of a compound on to the target words, it can also confer another type of apparent morphological structure on those words, that of word-forms bearing apparent derivational affixes. Examples are rare, but we may cite a series of nouns which in old French happened to end in -er -[er], such as bacheler 'batchelor', piler 'pillar', souler 'shoe', sangler 'boar', where -er was replaced (see, e.g., Meyer-Lübke $1921=1966$ ) by the common agentive suffix -ier (yielding modern French bachelier, pilier, soulier, sanglier). As argued in Maiden (1999:193), such developments seem to involve the creation of a kind of internal structure for these words, such that a root is followed by a derivational suffix - even though the 'root' has no independent existence outside the target word, and the suffix has no clear derivational function. The replacement of -er by -ier is, almost certainly, also favoured by the phonological resemblance between the endings.

It should be noted that $F E$ effects may be observed at the level of writing as well as, or instead of, in phonology. It is in the nature of folk-etymological forms that they pertain to spoken language and are generally not written unless they find their way into the standard language; but when, for example, beaupré 'bowsprit' acquires a written form in French, it is 
striking that the mode chosen to represent it orthographically is beau and pré, the orthographical forms of the words for 'beautiful' and 'meadow'. French offers sundry other ways of representing the phonological sequence [ворье] (**bauprai, **bopret, **beauprer and others), but standard French has settled on the spelling beaupré, giving the word an orthographically transparent, yet nonsensical, internal structure. As for the word diablette for diabète 'diabetes', cited by Orr (1963), while diabl- is clearly the word diable 'devil', whose presence in diablette may well be motivated by the fact that the disease is perceived as an evil, the final portion -ette -[عt] remains phonologically but not orthographically identical to the final portion of diabete. The decision to spell -ette rather than -ète in diablette is itself a manifestation of folk etymology, since the ending of the original has been replaced with the orthographic form of an exactly homophonous French (feminine) diminutive suffix -ette, and this occurs in the absence of any apparent diminutive meaning.

As many of these examples show, $F E$ rarely 'makes sense' at all, and indeed its effect is very often to 'make nonsense'. So much so that, for example, Alessio (1937/38:359) is led to comment on 'the people's need to associate words which are partly homophonous, even if they mean something quite different'. Initially, the affected word simply displays an arbitrary relation between signans and signatum, while under the effects of $F E$ it is liable to suggest meanings that range from irrelevant or misleading to downright contrary to sense. Some examples are Italian battisuocera 'cornflower' (but literally 'beat mother-in-law') or dialectal para'gusto 'gate to choir stall' (but literally 'stop taste'). Usually the result is a completely new 'compound', but Catanzarese bekka'mortu for Italian bergamotto deploys an existing compound meaning 'gravedigger' (literally, 'catch dead person'). French beaupré 'bowsprit' appears (especially in its written form) to comprise the two words 'beautiful' and 'meadow': quite evidently, the referent is not inherently 'beautiful', and by no stretch of the imagination a 'meadow'. Of course, some caution, and a degree of humility, is always in order from linguists: one needs to be careful, in any given case, that the selection of some replacing element is not prompted by an association which genuinely exists in the minds of speakers but may be unknown to the non-native-speaker linguist. While $F E$ typically involves the replacement of parts of long polysyllabic words by other words, it is possible to have complete folketymological replacement of one word by another, and this seems especially likely to happen with shorter words. A case in point, described by Hristea (1968:243), involves Romanian gaz metal literally 'gas metal', for gaz metan 'methane gas': clearly a 'gas' is not 'metal'. Remaining with 'gas', Wartburg (1925:18) reports for Loches (France) that acétylène 'acetylene (gas)' is replaced by the phrase la sainte-hélène, literally 'the Saint Helen'. This last example, by the way, suggests that folk-etymological reanalysis may involve not merely parts of words, or even whole words, but even, in principle, lexicalized multi-word phrases, such as the name of a saint. By the way, and as Loporcaro (2014:173) observes, the deployment of proper names in folk etymological creations - for example the case of Latin LIQUIRITIA 'licorice' becoming maurizio 'Maurice' in the Italian dialect of Taranto or sug de Lucrézia 'juice of Lucretia' in that of Modena - involves elements which may have reference but are semantically empty. Even longer words may be replaced by a whole word if there is sufficient phonological similarity. French échalote [e $\int \mathrm{al} \mathrm{t}$ t] 'shallot', in origin a loan from Occitan, is widely replaced in popular usage by charlotte [Jaslot] (a female proper name), a replacement possibly abetted by reanalysis of the initial vowel as part of a preceding (plural) definite article [le] (see Dauzat 1946:110).

One reason why it may, none the less, be tempting to see $F E$ as lending semantic motivation to the target words is that the results typically do manifest some kind of semantic association. Cases which seem semantically to 'motivate' a word are, however, generally the accidental effects of a different principle. The search for substitute forms begins in the same semantic field as the problem word, just as it involves phonologically similar forms (cf. 
Olschansky 1996:130; and Ronneberger-Sibold 1992 for a typology of the phonological factors involved). Apparent semantically 'motivating' cases of $F E$ can plausibly be described as a sideproduct of a search strategy which begins among items of similar form and of similar meaning. Romanian ferăstrău 'saw' probably derives from a possible Hungarian form *fürésztö (cf. Hristea 1958:515f.; but also Sala 2006:40f.), but its very common popular variant, fierăstrău, has clearly been influenced by the word fier 'iron'. This is not necessarily because speakers need to motivate the word semantically: after all, they know what it means, and they know perfectly well that a 'saw' is made of iron. The problem lies in the unanalysability of the borrowed polysyllable, so that speakers search to motivate it morphologically with 'familiar' constitutive elements, which they naturally seek in the semantic sphere of the referent. Since 'saws' are objects made of iron, the observed development is unsurprising. In Italian gelsomino 'jasmine', for example, a part of the original form is replaced by the word gelso 'mulberry'. A mulberry is of course also a plant, but it is one quite unlike a 'jasmine', from virtually every conceivable point of view (its appearance, its size, the uses to which it is put, its scent, and so forth). If the purpose of $F E$ were to 'motivate' semantically, then gelsomino would be a resounding failure, because the result would evoke a kind of plant which a jasmine most definitely is not. The word gelsomino is plain misleading, whereas its historically underlying form was not, being simply an opaque, arbitrary, sign. The frequent semantic resemblances between input and output in $F E$ are no more than an accidental by-product of a strategy adopted by speakers when they seek to replace elements of unfamiliar words with more familiar ones (cf. also Alinei 1997:21): they search first in the same general semantic area - just as they also tend to search for replacement forms that are phonologically similar.

There is another respect in which $F E$ can sometimes yield 'nonsense', again illustrated by gelsomino. This word has acquired the outward appearance of a compound word, comprising a noun plus some modifier (along the lines of, say, Italian terracotta literally 'earth baked'), except that the second element, -mino, corresponds to nothing in the Italian lexicon. The same holds of Abruzzese kampo'moillo 'chamomile', only the first element of which is analysable as an independent word. Within the 'folk-etymologized' word we end up with a secondary, residual form - indeed an example of what morphologists often call 'cranberry morphs' - a structural element to which no meaning can be ascribed, rather like the element cran, as opposed to berry, in English cranberry.

Probably the majority of historical linguists who have considered folk etymology have explicitly, or implicitly, reached the conclusion suggested by our Romance data, namely that semantic (re-)motivation of opaque words falls well short of explaining the mechanisms at work, moreover many see that what is at work is a process of imposing internal (compoundlike) internal structure on (usually) long words, by exploiting existing, familiar, forms regardless of the semantic results. Indeed, this is a view with a long pedigree: ${ }^{1}$

Nothing is in fact operative but the natural expectation of finding, in a word which looks like a compound, familiar elements; we expect [...] in a word which gives the impression of a compound, that its single elements should admit of connection with simple words. (Paul 1890:232; 236).

It is in many ways akin to analogy as a factor of group-formation counteracting the mechanical effects of phonetic change. The intervention of associative etymology may result in formal or semantic modifications, or in both [...]. (Ullmann 1951:91f.).

See further Saussure (1968:238;240); Wartburg (1925:17); Bloomfield (1935:450); Orr (1963); Hockett (1958:287); Orr (1963:11); Duchácek (1964); Coates (1987:324); Hamp (1992:427); Olschansky (1996:131-35); Blank (1997:306); Ronneberger-Sibold (2002:106;116). See also the distinction between 'secondary motivation' and 'secondary interpretation', in Olschansky (1996:146-48). 
popular etymology (or 'folk etymology') refers to the process in which an etymologically obscure word is reinterpreted and transformed in such a way that its form becomes familiar and - ideally - its meaning becomes transparent. (Geraerts 2010:64)

It is noteworthy that this 'formation of pseudo-compounds', so to speak, seems to be speakers' usual reaction to long and unfamiliar words. There is another kind of conceivable reaction, that they would simply tend to become phonologically 'scrambled', not in the ways habitually produced by phonetically based regular sound change, but rather through simple confusion of the segmental content and syllabic organization of the word. To take a hypothetical example, one could imagine some Italian dialect in which automobile 'automobile' became **aumotolebi, or **taumetolibo or **daumodolipe, or whatever. One's impression is that such 'scrambling' is not a common reaction in such cases, if it occurs at all, although the question deserves further study. There may indeed be phonological distortion of the original input, but this tends to occur as part of a structural reanalysis of the target word, so that the word comes to comprise existing words or morphemes. If there is 'scrambling' or 'distortion', it is in the form of dissonance between form and meaning. It certainly seems to be the case, however, that phonological similarity, within the same semantic sphere, can favour associative effects. Take for example the Romanian pârău 'stream, brook', which has developed a variant pârâu, now generally the preferred form. The word is in origin structurally opaque, being apparently borrowed from Albanian përrua. It happens to be not only semantically close to the native word râu 'river' (< Latin RIUUS), but also phonologically close to it, in that the final syllable of the word for 'stream' (-[rəu] $]$ ) differs in only one degree of vowel height from the word for 'river' ([riu] $]$ ). The second syllable of pârău has now generally been replaced by -râu. Now the plural of original pârău is pâraie (in common with a number of Romanian words ending in -ău: e.g., SG f(i)erăstrău 'saw' - PL $f(i)$ erăstraie). However, this folk-etymological replacement of the final syllable of the word for 'stream' by the form of the word for 'river' generally occurs only in the singular, so that the plural corresponding to the innovatory singular pârâu remains untouched, as pâraie, and this result is a type of morphological alternation unique in Romanian just to this one word. The plural of the word for 'river' is râuri, and a corresponding plural pârâuri 'streams' is indeed occasionally attested, but it is unusual. So it is the singular, phonologically very similar to the word for 'river', which is affected by the latter, but not the plural, where the phonological resemblance is much smaller. This observation suggests that there is a perceptual dimension to FE: phonological similarity between the target word and some other word may induce speakers to suspect that within, say, pârău they may actually be hearing râu.

Gilliéron (see, e.g., Iordan and Orr 1970:173; Hillen 1973:90) believed that $F E$, far from being 'pathological' or involving just rare and obscure words, was a constant and continual process in human language. If we include purely semantic $F E$, he might have been right, but the morphological manifestations of the phenomenon do seem characteristically to involve speakers' reactions to rare and unfamiliar lexical items. None the less, there is probably far more 'folk-etymologizing' at work in language than we ordinarily recognize. French examples such as éclaircité (comprising éclair 'light, lightning') for électricité 'electricity', or apétirif (containing an element homophonous with appétit 'appetite'), for apéritif 'aperitif', cited anecdotally by Orr (1963:10), seem to be ephemeral and have apparently never become established even as substandard variants. They are, no doubt and as Orr suggests, representative of processes which are permanently at work but rarely gain traction in the language, because they tend to be filtered out under the influence of the written standard (see also Dauzat 1946:109f.). It should be borne in mind that writing offers precisely the fixedness and structural clarity that tends to be lacking in speech. The examples that come to the notice of linguists often 
do so because the effect is comical. The true extent of the phenomenon remains difficult to assess, and its manifestations should not be too lightly dismissed just because they are often ephemeral or a matter of anecdotal report.

Folk etymology has a rather interesting theoretical implication, in that it suggests the independence, in language change, of form from the meaning with which it is (usually arbitrarily) associated. This implication has traditionally not been recognized: for example, an early and influential survey of folk etymological phenomena in Italo-Romance (Jaberg 1930), considers 'form' - understood purely as phonological substance — as indissolubly linked to semantic content. In fact, it is possible to redeploy meaning-bearing forms in abstraction from their associated meanings, using them, for example, to create word forms which clearly have the structure of compounds, but lack the content of the associated parts. It chimes with a general distinction in linguistic theory between 'meaning' and 'motivation', the latter relabelled 'iconymy' (iconimia). The latter is pervasive (especially in the formation of compounds) and involves what Alinei terms 'recycling of pre-existing signs'. A sign is 'motivated' (is an 'iconym') by virtue simply of being a familiar member of the existing stock of signs in a language, which makes it available as an element in the creation of new lexemes. For Alinei (1997:16), this 'motivation' is not 'an aspect of the nature of the sign, but an expedient by which the arbitrary sign may immediately be apprehended by all'. The 'iconym' has only a 'publicizing function, it is a name that has lost its own qualities to become the label of a new referent, a label which is already known and serves only to publicize that referent'. FE seems to be an instance of Alineian 'sign-recycling', for it involves signifiers being manipulated independently of their conventional meanings. That speakers can manipulate the 'form' side of signs can be illustrated, finally, by the following example, originally brought to light by Wartburg (1925:24); see also Baldinger (1973:258). This may not be a conventional case of 'folk etymology', but it is a rather spectacular example of associative morphological effects, such that the structure of one word influences that of another, in the complete and utter absence of any semantic link. In the Occitan dialect of La Canourgue (Lozère, southern France), Latin ASINUS 'donkey' and ACINUS 'berry' became homophonous, in the form 'aze, through regular sound change. Later, 'aze 'donkey' was replaced by its (near) synonym, the feminine noun 'saumo (originally 'beast of burden'), but this lexical replacement strikingly affected not only 'aze in the meaning 'donkey', but equally 'aze in the meaning '(black)berry', so that 'saumo comes to represent both. In this way, a lexical replacement whose motivation is, at first, synonymy (one meaning of 'aze, and the meaning of 'saumo, are the same) undergoes a reanalysis such that replacement is sensitive no longer to shared lexical meaning, but merely to the fact that both 'aze and 'saumo are lexical forms of the language, so that when the latter replaces the former in one of its meanings, it equally does so in the other homophone, of unrelated meaning. For futher discussion of this case and its implications, see Maiden (2008). The inherent dissociation between form and content in $F E$ is further evident in the Romanian by-form filigram, for filigran 'filigree', mentioned above. The source of final -gram is a large series of learnèd and technological words ending in -gram-, a formative of Greek origin and derived from the Greek verb 'to write': e.g., telegram $(\breve{a})$ 'telegram', radiogramă 'radiogram', fonogramă 'sound recording', program 'programme', anagram $(\breve{a})$ 'anagram', pentagramă 'pentagram'. Now the connexion with 'writing' in these words is likely to be apparent only to someone with a knowledge of Greek. For ordinary speakers, -gram- is surely little more than an element which frequently occurs at or towards the end of a series of erudite or technical words. It is simply a recurrent, discrete, piece of wordstructure without identifiable distinct meaning, and as such it is available for incorporation into the erudite, technical word 'filigree'.

In conclusion, there is no reason to believe that $F E$ is in any way peculiar to the Romance languages. There is reason, however, to think that it might be especially common in languages that are like Romance in possessing a productive source of new and perhaps unfamiliar 
polysyllabic words, as manifest particularly in learnèd word-forms entering the standard languages from, say, Classical Latin or Ancient Greek.

\section{Contamination}

Contamination (a term first used by Paul 1890=1970:161) differs from FE both on the formal and on the semantic side. Whereas FE characteristically involves formal interference between words at the level of 'morphemes' (here understood as continuous stretches of phonological substance associated with a particular lexical or grammatical meaning), often, as we have seen, independently of any associated meanings, contamination seems typically — although not always - to involve submorphemic phonological 'fragments', and to act between words which are semantically linked. Some classic examples in the early history of Romance languages are the development of Latin CRASSUS 'fat' under the influence of the semantically similar *'grossu 'large', yielding, e.g., Romanian gras, Italian grasso, French gras 'fat' (see, e.g., DÉRom, s.v. */'grass-u/). The stressed vowel of Romanian greu 'heavy', Italian greve 'heavy, painful' (see $R E W$, s.v. gravis), reflects the effects on Latin GRAUIS 'heavy' of its antonym LEUIS 'light' (see also Malkiel 1951:494-497). French framboise 'raspberry' reflects the influence on original bramboise ( $<$ old Frankish *brambasi) of the reflex of FRAGA (the source of French fraise) 'strawberry' (cf. FEW, s.v. *brambasi). Typically, the words implicated in contamination are alternative, or opposite, terms in tightly organized paradigmatic series, such as kinship expressions or antonyms, and perhaps especially words also liable to be recited as lists, such as numerals, or names of days of the week or of months. It is possible, where such 'list' words are concerned, that there is a 'syntagmatic' as well as a 'paradigmatic' component to contamination, speakers phonologically anticipating, or maintaining, phonological portions of following or preceding terms in the list.

Romance names of weekdays show widespread contamination effects. The Latin antecedents mainly had the form 'genitive form of name of deity' + DIES 'day': LUNAE DIES 'day of the moon, Monday', then, MARTIS DIES (Mars), MERCURII DIES (Mercury), IOUIS DIES (Jupiter), UENERIS DIES (Venus). The Spanish continuants (which do not preserve the word for 'day'), are lunes, martes, miércoles, jueves, viernes. The element -es continues the Latin third declension genitive ending -IS although, crucially, genitive case-marking is extinct in most Romance languages, so that -es has no morphological status. The appearance of the element es in lunes and miércoles has no etymological or historical phonological explanation, and is plainly due to contamination from the other words in the series. We have an example of 'prosodic' contamination in the word for 'Wednesday'. In Spanish, and across the Romance languages it carries, or carried, stress on the first syllable rather than the second, contrary to what is predicted from Latin MERCÚRII (cf. also Romanian miércuri, Neapolitan 'mjerkuri, Sardinian 'merkuris). It seems likely that the fact that the names of all other weekdays (except Sunday) are stressed on the first syllable, and perhaps especially the model of 'Friday' (UÉNERIS (DIES): cf. Romanian vineri), led to the stress-shift in 'Wednesday'. The names of the last four months of the year were in Latin SEPTEMBER, OCTOBER, NOUEMBER, DECEMBER. 'October' is slightly aberrant, in that it does not end in -EMBER. The pattern we find in Italian continues this, and is one widely reflected across Romance: settembre, ottobre, novembre, dicembre. In two Romance varieties, apparently independently, the 'anomaly' has been 'corrected', albeit only in respect of the consonant: in the area around Naples (AIS map 325), one finds for example o't:umbrə (alongside se't:عmbrə, etc.); in Romanian we have septembrie, octombrie, noiembrie, decembrie. In some dialects of north-western Italy (see AIS maps 322/323), we find that the final consonant of the word for 'July' (< IULIUS), expected on the basis of its etymology and regular sound change to be [j], is instead [n], the consonant in fact expected for reflexes of IUNIUS 'June': thus, Cortemilia (AIS point 176) gives expected Jyn 'June', lyj 'July', but Vico Canavese (AIS point 133) Jyn 'June', lyn or lyj 'July', Corneliano d'Alba (AIS point 165) fy:^ 
'June', ly:n 'July'. Numerals provide fewer examples but, for example, it seems possible that the final -[i] of Italian dieci '10' (and the numbers from undici '11' to sedici '16'), corresponding to Latin DECEM, UNDECIM...SEDECIM, reflects the influence of venti '20'. The expected final vowel for ' 10 ', etc., is -e (and the type diece is widely attested), while final [i] is predicted only for the reflex of Latin UIGINTī '20'. In some localities (e.g., AIS map 288 points Nemi 662, Santa Francesca 664 in southern Lazio), ['djefi] '10' seems in turn to have influenced ['novi] '9', for expected, and usual, ['nove] ( $<$ NOUEM).

An example of contamination in kinship terms concerns the reflexes of Latin SOCRUS 'mother-in-law', and NURUS 'daughter-in-law'. The Romance outcomes of these words (allowing for an adjustment in inflexion class and some other details), are the phonologically predictable ones, except that the stressed vowel of the word for 'daughter-in-law' is not the phonologically expected reflex (here marked '**') of Latin short $\mathrm{U}$, but that expected for a reflex of Latin short O: Spanish, suegra and nuera (not **nora); Italian, suocera and nuora (not **nora). The conclusion seems inescapable that 'daughter-in-law' has been 'contaminated' by the vowel of its correlative term 'mother-in-law'. The position in Romanian is a little more complex: the pair soacră vs noră (not expected **nură), although it shows a vocalic difference in the modern language, may be still have the same origin as the Spanish or Italian pairs of words. It may also show the influence of the vowel of soră 'sister' (< old Romanian soru < SÓROR), and the influence of 'sister' is unmistakable in a particular morphological peculiarity. Romanian soră has a uniquely irregular plural suróri (< SORÓRES), and just one other word, norăa, has been 'contaminated' by this peculiar root-allomorph: the modern language has singular noră - plural nuróri. ${ }^{2}$ Malkiel (1992) discusses the intriguing (but frankly speculative) idea of a kind of contaminatory 'contagion', the replacement of the expected vowel in the reflex of NURUS in early Romance having allegedly entrained other anomalous developments of the stressed vowel in reflexes of the phonological similar Latin words for which the predictable stressed vowel is *[o]: NODUS 'knot', NUX 'nut' (yielding dialectal (Asturian) nuedu, Sp. nuez), and NUPTIAE 'wedding', yielding (at least as Malkiel suggests) Italian nozze (['nots:e]). An example of contamination between lexical opposites involves the reflexes of Latin DEŌRSUM 'downwards' and SŪRSUM 'upwards': while in Romanian, for example, we have the expected outcomes jos and sus, Italian giù and su show contamination of the former by the latter (see further Malkiel 1951:497-502).

Membership of tightly organized semantic series such as day-names or kinship terms does not seem to be an absolutely necessary condition for contamination to occur. In some cases, a much looser semantic or functional relation seems sufficient if the words involve rhyme or assonance. Thus, in some north-western Italo-Romance and Gallo-Romance varieties, the reflex of proto-Romance modal verbs *vo'lere 'want' affects that of * po'tere 'be able' in respect of the root-final consonant for the further morphological ramifications of this development. As shown by AIS maps $1694 / 1701,{ }^{3}$ while the normal distinction is the type exemplified infinitive by volere vs potere or third person singular present indicative vuole vs può, as found in standard Italian, one finds in, say, Valdieri, vu'ler and pu'ler, vol and pol, with 'contamination' of the root-final consonant. In Italian, the reflex of Latin SPURCUS is sporco 'dirty', pronounced not **['sporko], as regular historical phonetic development would predict, but ['sporko], which is almost certainly influenced by porco (['porko]) 'pig'. This is surely due to the belief that pigs are dirty animals, but such a loose semantic association seems inadequate on its own to motivate contamination. In most Romance languages where its survives, the reflex of Latin MULGËRE 'to milk' retains its etymological [1] (e.g., Romanian mulge, Romansh mulscher). In some other varieties (e.g., old Spanish, old Galician, eastern Gascon), and most prominently in Italo-

\footnotetext{
${ }^{2}$ See also Malkiel (1951:490-494).

See also Frolla (1960), Garnier (1898:26-28;78;80); Azaretti (1982:221), for Ligurian dialects. For the morphological ramifications of this pattern, see Maiden (2018:209f.).
} 
Romance varieties, however, we find, in place of [1], an unexpected [n] (e.g., Italian mungere). This verb appears to have been 'contaminated' by Latin (E)MUNGERE 'to blow (some)one's nose', a development (see DÉRom, s.v. */'molg-e-/) favoured both by the substantial existing phonological similarity between these verbs, and the semantic resemblance involving 'extraction of a bodily secretion'. Merlo (1906:444) also thinks that Italian mora ['mora] 'blackberry' (instead of expected *['mora] from Latin MŌRA) owes its vowel to the influence of the adjective moro 'black/dark(-haired)' (feminine mora ['mora], from Latin MAURA), presumably due to the resemblance in colour. The unexpected stressed vowel of Italian soffre ['soffre] 's/he suffers', instead of etymologically expected **['soffre], is ascribed by Rohlfs (1966:89) to the influence of the phonologically similar offre ['offre] 's/he offers', despite the lack of semantic similarity.

We have seen various examples of contamination such that the exponent of one lexical meaning undergoes formal modification of some kind under the influence of the exponent of another related meaning. Some Romance varieties, however, display a remarkable example of contamination such that the morphological influence of one lexeme on a semantically associated one is manifested not in the direct exponent of the lexical meaning, but in the inflexional endings. The contamination takes the form of a change of inflexion class such that the 'contaminated' word joins the distinctive inflexion class of the 'contaminator'. The 'contaminator' in this case is the reflex of Latin third conjugation PLUERE 'to rain', which usually belongs, according to variety, either to the Romance third conjugation, historically stressed on the root (e.g., Italian piovere), or to the Romance second conjugation, historically stressed on the ending (e.g., French pleuvoir). Now both the second and the third conjugations are distinctly 'closed', unproductive, inflexion classes in Romance languages: they comprise almost only 'old' words inherited from Latin, and do not acquire new members, but the verb 'to snow' turns out to be a striking exception. In most Romance languages, this verb is a neologism derived from the proto-Romance noun *'neve (< Lat. NIUEM) 'snow', and assigned to the most productive class for neologisms, namely the first conjugation: hence Spanish, Occitan nevar. In some Francoprovençal, Romansh, and Ladin varieties, however, there is obvious contamination of 'to snow' by 'to rain', but this is apparent not in the form of the lexical root, but in the introduction of the verb 'snow' into the otherwise closed second or third conjugation classes, ${ }^{4}$ thereby exactly mimicking the inflexional behaviour of the verb 'to rain' in the relevant localities. This behaviour can be observed for the relevant regions by inspection and comparison of ALF maps 904 and 1035, of AIS maps 366, 367, and 377, and of ALDI maps 530 and 607. Thus, in the Francoprovençal of Rhêmes-Saint-Georges (AIS point 121), we find third conjugation infinitives 'pluwrə and 'ncjvro, and past participles plu'yj and nc'yj; in the Engadine Romansh of Tschlin (ALDI point 1) third conjugation infinitives 'plovər and 'naivər; in the Ladin of San Cassiano ( $A L D I$ point 91) second conjugation infinitives plo'vai and no'vaj. There is an obvious semantic link with 'to rain', and the Romance root *nev- also has a phonological point of contact with *plov- just in the final consonant. No doubt these factors motivate the contamination of 'snow' by 'rain', but remarkably the manifestation of this associative effect lies in the assignment of 'snow' to the closed inflexional class with which 'rain' is characteristically (but by no means uniquely) associated, not in the lexical roots which are the ostensive exponents of the lexical meanings.

Contamination, in Romance languages as elsewhere, is an elusive phenomenon. It is not possible to state necessary or sufficient conditions for it to occur, nor to predict what its morphological effects will be when it does occur, nor even where in a given word-form those

\footnotetext{
${ }^{4}$ The claim that this verb could continue an alleged Latin verb nivere, made for example by Wartburg (FEW, s.v. *nı̌vicare), rests on extremely flimsy evidence, although the various problems with that claim cannot be pursued in more detail here. It is in fact clear that the general Latin verb for 'snow' was NINGUERE, continued in some eastern Romance varieties, and that the forms we are discussing here are Romance innovations.
} 
effects may appear. It tends to occur among words organized into semantically-based paradigmatic series, and often to effect changes in single, submorphemic, segments. Yet, as shown in the example of the verb 'to snow', above, it is actually possible for it to occur outside those elements of word structure which would seem the obvious target of contaminatory effects. The facts of contamination suggest that speakers do not map the semantic components of wordforms directly onto those elements of the word-forms which may appear transparently, and separately, to correspond to them. If, say, just the stressed vowel of the word for 'mother-inlaw' can contaminate that for 'daughter-in-law', reflecting the semantic association, it suggests that even fragments of the string of sounds meaning 'mother-in-law' can be associated with that meaning, and if, say, the second conjugation ending found in the infinitive of the verb 'rain' can influence the infinitive of the semantically similar verb 'snow', then we have evidence that, for speakers, lexical meaning is, so to speak, 'smeared' across the entire word-form, and not confined to the root. Observations of this kind seem generally to be consistent with the view taken in 'Word-and-Paradigm' models of morphology (see, for example, Blevins 2016) that it is entire word-forms, and the paradigmatic relations in which they stand to other word-forms, which are the basic units of analysis in morphology, and that there is no basic, inherent, mapping of units of form onto units of meaning below the level of the word.

As with $F E$, there is no reason to imagine that contamination is special to Romance languages. One imagines that it could occur in any language where words belonging to the same closely related semantic group also show some degree of phonological similarity.

\section{References}

ALD1 = Goebl, H., Böhmer, H., Gislimberti, S., Kattenbusch, D., Perini, E., Szekely, T., Dautermann, I., Heissmann, S., Hofmann, U., Kozak, A., Pamminger, H, Rössler, H.-M., Bauer, R., \& Haimerl, E. (1998). Atlant linguistich dl ladin dolomitich y di dialec vejins/Atlante linguistico del ladino dolomitico e dei dialetti limitrofi/Sprachatlas des Dolomitenladinischen und angrenzender Dialekte, Part 1. Wiesbaden: Reichert.

Alessio, G. (1937/1938). Deformazione ed etimologia popolare nei dialetti dell'Italia meridionale. Rendiconti del reale Istituto Lombardo di Scienze e Lettere 71, 357-407.

$A L F=$ Gilliéron, J. and Edmont, E. (1902-1910). Atlas linguistique de la France. Paris: Champion.

AIS = Jaberg, K. \& Jud, J. (1928-1940). Sprach- und Sachatlas Italiens und der Südschweiz. Zofingen: Ringier.

Alinei, M. (1997). Principi di teoria motivazionale (iconimia) e di lessicologia motivazionale (iconomastica). In Mucciante, L. and Telmon, T. (eds) Lessicologia e lessicografia. Atti del Convegno Lessicologia e lessicografia. Rome: Il Calamo, 11-36.

Azaretti, E. (1982). L'evoluzione dei dialetti liguri esaminata attraverso la grammatica storica del ventimigliese. Sanremo: Casablanca.

Baldinger, K. (1973). A propos de l'influence de la langue sur la pensée. Etymologie populaire et changement sémantique parallèle. Revue de Linguistique Romane 37, 239-273.

Béguelin, M.-J. (2007). Étymologie 'populaire', jeux de langage et construction du savoir lexical. Semen 15: http://semen.revues.org/2414

Bertolotti, R. (1958). Saggio sulla etimologia popolare in latino e nelle lingue romanze. Milan: Paideia.

Blank, A. (1997). Prinzipien des lexikalischen Bedeutungswandels am Beispiel der romanischen Sprachen, Tübingen, Niemeyer.

Blevins, J. (2016). Word and Paradigm Morphology. Oxford: Oxford University Press.

Bloomfield, L. (1935). Language. London: Allen and Unwin.

Bolinger, D. (1992). Sound symbolism, in Bright, W. (ed.) International Encyclopedia of Linguistics. Oxford: Oxford University Press, 4, 28-30. 
Coates, R. (1987). 'Pragmatic sources of analogical reformation'. Journal of Linguistics 23, 319340.

Dauzat, A. (1946). Les Patois: évolution, classification, étude. Paris: Delagrave.

DÉRom = Buchi, É. \& Schweickard, W. (ed.) (2008-): Dictionnaire Étymologique Roman (DÉRom). Nancy: ATILF. http://www.atilf.fr/DERom.

Duchácek, O. (1964). L'attraction lexicale. Philologica Pragensia 7, 65-76.

$F E W=$ von Wartburg, W. (1928-). Französisches Etymologisches Wörterbuch. Bonn: Klopp.

Frolla, L. (1960). Grammaire monégasque. Monaco: Imprimerie Nationale.

Garnier, C. (1898). Deux patois des Alpes-maritimes italiennes: grammaires et vocabulaires méthodiques des idiomes de Bordighera et de Realdo. Paris: Leroux.

Geraerts, D. (2010). Theories of Lexical Semantics. Oxford: Oxford University Press.

Gilliéron, J. (1918). Généalogie des mots qui désignent l'abeille. Paris: Champion.

Hamp, E. (1992). Etymology, in Bright, W. (ed.) International Encyclopedia of Linguistics. Oxford: Oxford University Press, 1, 424-429.

Hillen, W. (1973). Sainéans und Gilliérons Methode und die romanische Etymologie. Bonn: Romanisches Seminar der Universität Bonn

Hockett, C. (1958). A Course in Modern Linguistics. New York: Macmillan.

Hristea, T. (1958). Etimologii populare. Studii și cercetări lingvistice 9, 511-531.

Hristea, T. (1968). Probleme de etimologie: studii, articole, note. Bucharest: Editura Științifică.

Iordan, I. \& Orr, J. (1970). An Introduction to Romance Linguistics. Its Schools and Scholars. Berkeley / Los Angeles: University of California Press.

Jaberg, K. (1930). Spiel und Scherz in der Sprache, in Maync, H. (ed.), Festgabe Samuel

Singer. Überreicht zum 12. Juli 1930 von seinen Schülern, Tübingen, Mohr, 67-81.

Kilani Schoch, M. (1987). Introduction à la morphologie naturelle. Berne: Lang.

Lauwers, P. (2002). Jules Gilliéron: contrainte et liberté dans le changement linguistique', in Lauwers, P., Simoni-Aurembou, M.-R., and Swiggers, P. (eds). Géographie linguistique et biologie du langage: autour de Jules Gilliéron. Louvain / Paris / Dudley: Peeters, 79-112.

Maiden, M. (1999). Romance historical morphology and empty affixes, in Embleton, S., Joseph, J. \& Niederehe, H.-J. (eds.), The Emergence of the Modern Language Sciences: Studies on the transition from historico-comparative to structural linguistics in honor of E. F. Konrad Koerner, Amsterdam-Philadelphia: Benjamins, 485-498.

Maiden, M. (2008). Lexical nonsense and morphological sense: on the real importance of 'folk etymology' and related phenomena for historical linguists, in Eypórsson, P. (ed.) Grammatical Change and Linguistic Theory: The Rosendal Papers. Amsterdam: Benjamins, 307-328.

Maiden, M. (2018). The Romance Verb. Morphomic Structures in Diachrony. Oxford: Oxford University Press.

Malkiel, Y. (1951). Lexical polarization in Romance. Language 27, 485-518

Malkiel, Y. (1992). The transmission into Romance of Latin NŌDUS, NŬPTIAE, NŬRUS, and NÜX: diachronic interplay of phonetic and semantic analogies, in Diachronic Studies in Lexicology, Affixation, Phonology: Edita and Inedita 1979-1988. Amsterdam: Benjamins, 207230.

Merlo, C. (1906-07). Dei continuatori del lat. ille in alcuni dialetti dell'Italia centromeridionale. Zeitschrift für romanische Philologie 30: 11-25, 438-54; 31: 157-63.

Meyer-Lübke, W. (1921=1966). Historische Grammatik der französischen Sprache. II. Wortbildungslehre. Heidelberg: Winter.

Olschansky, H. (1996). Volksetymologie. Tübingen: Niemeyer.

Orr, J. (1963). L'étymologie populaire, in Essais d'étymologie et de philologie françaises. Paris: Klincksieck, 1-15.

Paul, H. $(1890=1970)$. Principles of the History of Language [transl. H. Strong]. College Park, Maryland: McGrath. 
Pisani, V. (1960). Über Volksetymologie. Studii si cercetări lingvistice 11, 633-643

Pöckl, W., Rainer, F., Pöll, B. (2003). Einführung in die Romanische Sprachwissenschaft. Tübingen: Niemeyer.

$R E W=$ Meyer-Lübke, W. (1972). Romanisches Etymologisches Wörterbuch. Heidelberg: Winter.

Rohlfs, G. (1966). Grammatica storica della lingua italiana e dei suoi dialetti. Fonetica. Turin: Einaudi.

Ronneberger-Sibold, E. (2002). Volksetymologie und Paronomasie als lautnachahmende Wortschöpfung, in Habermann, M., Müller, P., Munske, H. (eds) Historische Wortbildung des Deutschen. Tübingen: Niemeyer, 105-127.

Sala, M. (2006). Aventurile unor cuvinte românești I. Bucharest: Univers Enciclopedic.

Saussure, F. de (1968=1916). Cours de linguistique générale. Paris: Payot.

Ullmann, S. (1951). The Principles of Semantics. Glasgow: Jackson, Son \& Company.

Wartburg, W. von (1925). Zur Frage der Volksetymologie, in Homenaje ofrecido a Menéndez

Pidal I. Madrid: Hernando, 17-27.

\section{Further reading}

Baldinger, K. (1973). A propos de l'influence de la langue sur la pensée. Etymologie populaire et changement sémantique parallèle. Revue de Linguistique Romane 37, 239-273.

Béguelin, M.-J. (2007). Étymologie 'populaire', jeux de langage et construction du savoir lexical'. Semen, 15: http://semen.revues.org/2414

Coates, R. (1987). Pragmatic sources of analogical reformation. Journal of Linguistics 23, 319340.

Duchácek, O. (1964). L'attraction lexicale. Philologica Pragensia 7, 65-76.

Maiden, M. (2008). Lexical nonsense and morphological sense: on the real importance of "folk etymology" and related phenomena for historical linguists, in EyPórsson, P. (ed.) Grammatical Change and Linguistic Theory: The Rosendal Papers. Amsterdam: Benjamins, 307-328.

Olschansky, H. (1996). Volksetymologie. Tübingen: Niemeyer.

Orr, J. (1963). L'étymologie populaire, in Essais d'étymologie et de philologie françaises. Paris: Klincksieck, 1-15.

Ronneberger-Sibold, E. (2002). Volksetymologie und Paronomasie als lautnachahmende Wortschöpfung, in Habermann, M., Müller, P., Munske, H. (eds) Historische Wortbildung des Deutschen. Tübingen: Niemeyer, 105-127. 